\title{
Responses of GLP1-secreting L-cells to cytotoxicity resemble pancreatic $\beta$-cells but not $\alpha$-cells
}

\author{
Srividya Vasu, R Charlotte Moffett, Neville H McClenaghan and Peter R Flatt \\ SAAD Centre for Pharmacy and Diabetes, University of Ulster, Cromore Road, Coleraine BT52 1SA,
} Northern Ireland, UK

Correspondence should be addressed to $S$ Vasu

Email

s.vasu@ulster.ac.uk

\begin{abstract}
Little is known about responses of intestinal L-cells to chemical or cytokine-mediated attack and how these compare with pancreatic $\beta$ - or $\alpha$-cells. Administration of streptozotocin to mice induced severe diabetes, islet lymphocytic infiltration, increased $\alpha$-cell proliferation and decreased numbers of $\beta$ - and L-cells. In vitro, streptozotocin and cytokines reduced cell viability with higher lethal dose 50 values for $\alpha$-TC1 cells. mRNA expression of Glut2 was lower and Cat was greater in GLUTag and $\alpha$-TC1 cells compared with MIN6 cells. Cytotoxins affected the transcription of genes involved in secretion in GLUTag and MIN6 cells. They are also involved in upregulation of antioxidant defence enzymes, transcription of $N f_{K} B$ and Nos2, and production of nitrite in all cell types. Cytotoxin-induced DNA damage and apoptosis were apparent in all cells, but $\alpha$-TC1 cells were less severely affected. Thus, responses of GLP1-secreting L-cells to cytotoxicity resemble $\beta$-cells, whereas $\alpha$-cells are resistant due to differences in the expression of genes involved in cytotoxicity or antioxidant defence.
\end{abstract}

Key Words

- Cytokine

- L cells

- beta cells

- alpha cells

- streptozotocin

\section{Introduction}

In type 1 diabetes, proinflammatory cytokines such as interleukin $1 \beta$ (IL1 $\beta$ ), interferon $\gamma$ (IFN $\gamma$ ) and tumour necrosis factor $\alpha(\mathrm{TNF} \alpha)$, released by autoimmune cells, are important mediators of pancreatic $\beta$-cell death (Cnop et al. 2005). Cytokines activate master transcription factors nuclear factor $\kappa \mathrm{B}(\mathrm{NF} \kappa \mathrm{B})$ and STAT1 which transactivate the expression of genes involved in apoptosis and nitric oxide production (Gurzov et al. 2008, Moore et al. 2012). Nitric oxide participates in diffusion-controlled reaction with superoxide radical to form toxic peroxynitrite, which interacts with DNA, lipids and proteins via direct or indirect oxidative reactions (Pacher et al. 2007). Such reactions trigger necrosis or apoptosis due to limited expression of antioxidant enzymes in pancreatic $\beta$-cells
(Lenzen 2008, Mechlovich et al. 2010). The pathogenesis of cytokine-mediated $\beta$-cell death has been studied extensively using non-obese diabetic mice which demonstrate spontaneous autoimmunity and rodent $\beta$-cell lines.

Administration of streptozotocin in multiple low doses to mice destroys pancreatic $\beta$-cells in a fashion similar to cytokines (Shehata et al. 2011). Thus, unlike a single dose of streptozotocin which causes overt diabetes due to $\beta$-cell death caused by DNA damage-induced depletion of cellular NAD (Elsner et al. 2000, Lenzen 2008), administration of small doses causes islet lymphocyte infiltration and insulitis similar to that observed in islets of patients with type 1 diabetes (Shehata et al. 2011). Interestingly, these events are associated with an increase in $\alpha$-cell mass in diabetes

Published by Bioscientifica Ltd. 
(Li et al. 2000, Yoon et al. 2003), accompanied by hyperglucagonaemia which contributes to metabolic disarray (Li et al. 2000, Meier et al. 2011). In streptozotocin-treated mice, $\alpha$-cell mass expansion together with hyperglucagonaemia has been observed (Takeda et al. 2012, Vasu et al. 2014a). Thus, it is evident that $\alpha$-cells survive conditions that are toxic to $\beta$-cells and hence appear to be more resistant to damage by cytotoxins. High expression of catalase, an antioxidant enzyme, was observed in pancreatic $\alpha$-cells of diabetic mice (Bloch et al. 2007), suggesting that these cells employ defence mechanisms to evade cell death induced by cytotoxins.

In addition to $\alpha$-cell expansion and hyperglucagonaemia, diabetes is associated with disturbances in the insulinotropic action and especially the secretion of GLP1 (Vilsboll et al. 2003, Holst 2007, Huml et al. 2011, Kielgast et al. 2011, Unger 2013). Recent investigations together with our unpublished observations have revealed that disturbances in the intestinal L-cell population may contribute to the loss-of-functional incretin response in diabetes (Kappe et al. 2014). In the context of type 1 diabetes pathogenesis, such disturbances may contribute to the observed metabolic abnormalities. Indeed, although pancreatic $\beta$-cell death is mediated by local inflammation, elevated systemic levels of IL1 $\beta$, IL6, IL17, IFN $\gamma$ and TNF $\alpha$ were reported in type 1 diabetic patients (Espersen et al. 1993, Basu et al. 2005, Hammed et al. 2012, Sarikonda et al. 2014). Ho et al. (2014) have also reported elevated levels of TNF $\alpha$ with reduced levels of anti-inflammatory cytokine (IL10) after streptozotocin treatment. Thus, enteroendocrine cells are exposed to cytokines and also other cytotoxic agents just as $\beta$-cells, but whether these cells are susceptible to damage causing their malfunction is unknown. Multiple low dose of streptozotocin provides a good model of type 1 diabetes pathogenesis (Kolb 1987, Kolb-bachofen et al. 1988, Lukic et al. 1998, Shehata et al. 2011) and offers a straightforward method to assess the effects of local inflammation on pancreatic islets and lowgrade systemic inflammation on intestinal L-cells.

The present paper seeks to answer two key questions. First, are intestinal L-cells susceptible to cytotoxic attack? Secondly, how do they compare with pancreatic $\alpha$ - and $\beta$-cells, in terms of antioxidant enzyme expression and ability to repair damage? To accomplish this, we investigated the effects of multiple low-dose streptozotocininduced diabetes on intestinal L-cells and pancreatic $\alpha$ - and $\beta$-cells. Furthermore, we compared the gene expression and cellular responses of GLUTag, an intestinal L-cell model, $\alpha$-TC1 clone 9 , a pancreatic $\alpha$-cell model, and
MIN6, a $\beta$-cell model after exposure to cytokines and streptozotocin.

\section{Materials and methods}

\section{Animals}

C57BL/6 mice, aged 8 weeks (Harlan UK Ltd, Shaw's farm, Blackthorn, UK) were housed individually in an airconditioned room at $22 \pm 2{ }^{\circ} \mathrm{C}$ with $12 \mathrm{~h}$ light and $12 \mathrm{~h}$ darkness cycle. Standard rodent pellet diet (Trouw Nutrition, Chesire, UK) and drinking water were supplied ad libitum. Streptozotocin $(50 \mathrm{mg} / \mathrm{kg}$ body weight, freshly prepared in ice-cold $0.1 \mathrm{M}$ sodium citrate buffer, $\mathrm{pH} 4.5$ ) was injected (i.p.) for 5 consecutive days to induce diabetes. Blood glucose concentrations were determined using an Ascencia Contour glucose meter (Bayer Healthcare). The animals were culled, with collection of blood and tissues 5 days after the last dose of streptozotocin injection. All animal procedures were carried out according to UK Home Office regulations (UK Animal Scientific Procedures Act 1986) and 'Principles of laboratory animal care' (NIH Publication no. 86-23, revised 1985).

\section{Cell culture and treatments}

MIN6 cells (courtesy of Prof. Sigurd Lenzen, Institute of Clinical Biochemistry, Hannover, Germany) and $\alpha$-TC1 clone 9 cells (courtesy of Prof. Kevin Doherty, University of Aberdeen) were cultured in 5\% $\mathrm{CO}_{2}$ and $95 \%$ air using DMEM (Gibco, Invitrogen) containing $25 \mathrm{mM}$ glucose, $10 \%(\mathrm{v} / \mathrm{v})$ foetal bovine serum and $1 \%(\mathrm{v} / \mathrm{v})$ antibiotics. The GLUTag cells (courtesy of Prof. DJ Drucker, University of Toronto, Canada) were cultured in the same medium, but containing $5.5 \mathrm{mM}$ glucose. All three cell lines were of murine origin. Recombinant human cytokines (Promokine, Heidelberg, Germany) or streptozotocin was added to the culture medium immediately before use. The viability of cells after cytotoxin treatment was assessed by 3-(4,5-dimethylthiazol-2-yl)-2,5-diphenyltetrazolium bromide (MTT) assay (Mosmann, 1983).

\section{Biochemical analyses}

Terminal blood samples were collected into fluoride/ heparin microcentrifuge tubes (Sarstedt, Nümbrecht, Germany) and centrifuged for $30 \mathrm{~s}$ at $13000 \mathrm{~g}$. Plasma was collected and stored at $-20^{\circ} \mathrm{C}$. Insulin accumulated in culture media following exposure of MIN6 cells to cytotoxins was measured by RIA (Flatt \& Bailey 1981). Glucagon and GLP1 in the culture media with $\alpha$-TC1 cells or GLUTag cells

Published by Bioscientifica Ltd. 
were measured by electrochemiluminescence assay using the Mouse/rat Glucagon Kit (total) or Total GLP1 Assay Kit (Multiarray system, Meso Scale Discovery, Rockville, MD, USA), as described previously (Irwin et al. 2012).

\section{Immunohistochemistry}

The resected pancreas and small intestine were fixed in $4 \%$ paraformaldehyde and processed using automated tissue processor (Leica TP1020, Leica Microsystems, Nussloch, Germany). The tissue sections ( $8 \mu \mathrm{m}$ thickness, sectioned using microtome, Shandon Finesse 325, Thermo Scientific, UK) were deparaffinised, rehydrated and probed with primary antibodies: mouse anti-insulin antibody (1:500; Abcam), guinea-pig anti-glucagon antibody (PCA2/4, 1:200; raised in-house), rabbit anti-Ki67 antibody (ab15580, Abcam) or rabbit anti-GLP1 antibody (XJIC8, 1:200; raised in-house). The sections were then incubated with secondary antibody (Alexa Fluor 594 goat anti-guinea pig IgG (1:400) and Alexa Fluor 488 goat anti-rabbit IgG (1:400), Invitrogen) and mounted using anti-fade mounting medium. The slides were viewed under FITC filter $(488 \mathrm{~nm})$ or TRITC filter $(594 \mathrm{~nm})$ using a fluorescent microscope (Olympus System Microscope, model BX51) and photographed using the DP70 camera adapter system. For the analysis of infiltration of islets and small intestine by lymphocytes, pancreatic and intestinal tissue sections were stained using haematoxylin and eosin following established protocols. The images were analysed using $\mathrm{Cell}^{\wedge} \mathrm{F}$ analysis software, and islet area together with related parameters were measured using the closed polygon tool. The percentage pancreatic $\beta$ - or $\alpha$-cell area (\% of islet area or area of pancreas section) was calculated from insulin or glucagon-positive area/total islet area or total area of pancreatic section. Ki67/glucagonpositive cells were counted in a blinded fashion in $\sim 1500$ cells, and proliferation frequency was expressed as percentage of total cells analysed. For analysis of GLP1-positive cell distribution in small intestine, four tissue sections $(8 \mu \mathrm{m}$ thickness and sections were picked at an interval of ten sections) were stained for GLP1. GLP1-positive cells were counted in a blinded fashion and expressed as number per mucosal area $\left(\mathrm{mm}^{2}\right)$. For scoring insulitis, islets with lymphocyte infiltration (visible lymphocytes within islets) (Peterson et al. 1994) were counted in a blinded fashion and expressed as percent of total number of islets analysed.

\section{Real-time RT PCR}

mRNA was extracted using the RNeasy Mini Kit (Qiagen) following manufacturer's instructions and converted to
cDNA using superscript II reverse transcriptase - RNase H Kit (Invitrogen). Same amounts of mRNA were (under all conditions) for all three cell lines. The reaction mix of real-time RT PCR consisted of $12.5 \mu \mathrm{l}$ (Quantifast SYBR green PCR kit, Qiagen), $1 \mu$ primers (forward and reverse primers (between 90 and 110\% efficiency), Table 1, Invitrogen), $1 \mu \mathrm{l}$ cDNA and $9.5 \mu \mathrm{l}$ RNase free water. Amplification conditions were initial denaturation at $95^{\circ} \mathrm{C}$ for $5 \mathrm{~min}$, final denaturation at $95^{\circ} \mathrm{C}$ for $30 \mathrm{~s}$, annealing at $58{ }^{\circ} \mathrm{C}$ for $30 \mathrm{~s}$ and extension at $72{ }^{\circ} \mathrm{C}$ for $30 \mathrm{~s}$. Each PCR experiment included negative control, positive control (Actb; forward - TGGATCGGTGGCTCCATCCTGG; reverse - GCAGCTCAGTAACAGTCCGCCTAGA; product length $-130 \mathrm{bp}$ ) and melting curve analysis at a temperature range of $60-90{ }^{\circ} \mathrm{C}$. Real-time data were acquired using MiniOpticon two-colour real-time PCR detection system (BioRad). The results were analysed using $\Delta \Delta \mathrm{Ct}$ method and mRNA expression was normalised to Actb.

\section{Alkaline comet assay}

Cellular DNA damage after cytotoxin exposure was determined using alkaline comet assay (Lees Murdock et al. 2004). The gels were stained with 4',6-diamidino-2-phenylindole (DAPI) $(100 \mu \mathrm{g} / \mathrm{ml})$ and viewed using epifluorescent microscope (Olympus system microscope, model BX51). Densitometric and geometric parameters including \% tail DNA and olive tail moment were measured by CometScore software. Approximately, 100 cells per gel were analysed (Meerza et al. 2012, Sirota et al. 2014, Vasu et al. 2014b).

\section{Acridine orange/ethidium bromide assay for apoptosis}

Apoptosis induction was determined using acridine orange/ ethidium bromide staining (Vasu et al. 2014b). The cells were then mounted on glass slides and viewed using epifluorescent microscope (Olympus system microscope, model BX51) and photographed using digital camera adapter system (DP70). The cells with bright green nuclei were considered healthy, those with dense green nuclei (chromatin condensation) as early apoptotic, those with bright yellow nuclei and cytoplasm as late apoptotic and those with orange nuclei and cytoplasm as dead. Approximately 100 cells per replicate were analysed using cell counter plug-in of ImageJ software (Kempaiah \& Kisiel 2008, Noor et al. 2014).

\section{Nitrite assay}

Griess Reagent Kit (Invitrogen) was used to determine nitrite levels in culture supernatant according to the

Published by Bioscientifica Ltd. 
Table 1 The mouse primers used in this study. Primer efficiencies were between 90 and $110 \%$. Mouse gene nomenclature guidelines were followed for gene symbols

\begin{tabular}{|c|c|c|c|c|}
\hline Official gene symbol & Alias/common name & Primer sequence $\left(5^{\prime}-n t-3^{\prime}\right)$ & $\begin{array}{l}\text { Product } \\
\text { size }(b p)\end{array}$ & $\begin{array}{l}\text { Annealing } \\
\text { temperature } T_{\mathbf{m}}\left({ }^{\circ} \mathrm{C}\right)\end{array}$ \\
\hline \multicolumn{5}{|l|}{ Secretory function } \\
\hline Ins1 & Insulin & $\begin{array}{l}\mathrm{F} \text { - TAACCCCCAGCCCTTAGTGA } \\
\mathrm{R} \text { - ACACACCAGGTAGAGAGCCT }\end{array}$ & 194 & 57 \\
\hline Gcg & Proglucagon & $\begin{array}{l}\mathrm{F} \text { - ACACCTGTTCGCAGCTCAGGC } \\
\mathrm{R} \text { - AAATCTTGGGCACGGCGGGAG }\end{array}$ & 261 & 57 \\
\hline Slc2a2 & Glucose transporter 2 & $\begin{array}{l}\mathrm{F} \text { - ACCGGGATGATTGGCATGTT } \\
\mathrm{R} \text { - GGACCTGGCCCAATCTCAAA }\end{array}$ & 140 & 56 \\
\hline Pcsk1 & $\begin{array}{l}\text { Pc1/3, proprotein convertase } \\
\text { subtilisin/kexin type } 1\end{array}$ & $\begin{array}{l}\text { F - GAATGGGCGGCGGAGATCCC } \\
\text { R - CGGGACCTCCGAGGATGGCTT }\end{array}$ & 140 & 58 \\
\hline Pcsk2 & $\begin{array}{l}\text { Pc2, proprotein convertase } \\
\text { subtilisin/kexin type } 2\end{array}$ & $\begin{array}{l}\text { F - CCGAGGAGGAGCTGAAAATGCAGAT } \\
\text { R - CTGGCTGGCAGGGGTGCGAAT }\end{array}$ & 104 & 55 \\
\hline \multicolumn{5}{|c|}{ Antioxidant defence } \\
\hline Cat & Catalase & $\begin{array}{l}\mathrm{F} \text { - TCAGGGCCGCCTTTTTGCCT } \\
\mathrm{R} \text { - TCGAGCGCGGTAGGGACAGT }\end{array}$ & 94 & 57 \\
\hline Gpx1 & Glutathione peroxidase 1 & $\begin{array}{l}\mathrm{F} \text { - CCCCACTGCGCTCATGACCG } \\
\mathrm{R} \text { - CGAAAGCGGCGGCTGTACCT }\end{array}$ & 135 & 58 \\
\hline Sod1 & Superoxide dismutase (soluble) & $\begin{array}{l}\mathrm{F} \text { - TTCCGTCCGTCGGCTTCTCGT } \\
\mathrm{R} \text { - CGCACACCGCTTTCATCGCC }\end{array}$ & 96 & 58 \\
\hline Sod2 & $\begin{array}{l}\text { Superoxide dismutase } 2, \\
\text { mitochondrial }\end{array}$ & F - TTCCCAGGATGCCGCTCCGT & 134 & 58 \\
\hline & & R - GCGTCTGCTAGGCAGCGTCC & & \\
\hline \multicolumn{5}{|c|}{ К } \\
\hline Bax & BCL2-associated $X$ protein & $\begin{array}{l}\mathrm{F} \text { - TGAGCGAGTGTCTCCGGCGA } \\
\mathrm{R} \text { - CACGCGGCCCCAGTTGAAGT }\end{array}$ & 155 & 57 \\
\hline$B c / 2$ & B cell CLL/lymphoma 2 & $\begin{array}{l}\text { F - ATGGCCCCAGCATGCGACCTC } \\
\text { R - CACTTGTGGCCCAGGTATGCACC }\end{array}$ & 115 & 58 \\
\hline$N f k b 1$ & $\begin{array}{l}\text { Nuclear factor of kappa light poly- } \\
\text { peptide gene enhancer in B cells } 1\end{array}$ & $\begin{array}{l}\mathrm{F} \text { - AGAAGTCTGGGCGCACAGCG } \\
\mathrm{R} \text { - TGGTGGACCCTCTTCCGGCC }\end{array}$ & 153 & 58 \\
\hline Nos2 & $\begin{array}{l}\text { Nitric oxide synthase } 2, \\
\text { inducible }\end{array}$ & $\begin{array}{l}\mathrm{F} \text { - GCTCGCTTTGCCACGGACGA } \\
\mathrm{R} \text { - AAGGCAGCGGGCACATGCAA }\end{array}$ & 146 & 58 \\
\hline \multicolumn{5}{|c|}{ 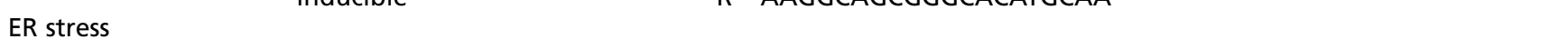 } \\
\hline Hspa4 & Hsp70, Heat shock 70 kDa protein 4 & $\begin{array}{l}\mathrm{F} \text { - GCACTGTGCACTGTACCAGGGGA } \\
\mathrm{R} \text { - TCTCCAGGGAACTGGGCAGCTA }\end{array}$ & 135 & 58 \\
\hline Hspa5 & $\begin{array}{l}\text { BiP, Heat shock } \\
\quad 70 \text { kDa protein } 5\end{array}$ & $\begin{array}{l}\mathrm{F}-\text { TGCGTGTGTGTGAGACCAGAAC } \\
\mathrm{R}-\text { CCCCAAGTCGATGCCGACCAC }\end{array}$ & 218 & 57 \\
\hline \multicolumn{5}{|l|}{ Cytokine receptors } \\
\hline$\| 11 r 1$ & IL1 receptor 1 & $\begin{array}{l}\mathrm{F} \text { - TAATGCTGTCCTGGGCTGACT } \\
\mathrm{R} \text { - CATCCAGCGACATTTCTCCCC }\end{array}$ & 100 & 58 \\
\hline Ifngr1 & IFN $\gamma$ receptor 1 & $\begin{array}{l}\mathrm{F} \text { - GGAGTGGAGCTTTGACGAGC } \\
\mathrm{R} \text { - TCCCAGCATACGACAGGGTT }\end{array}$ & 106 & 58 \\
\hline Tnfrsf1a & TNF receptor superfamily $1 a$ & $\begin{array}{l}\mathrm{F} \text { - GTAGTGGGCCTCGTGCTTTC } \\
\mathrm{R} \text { - TGTGGGTGTGGCTTTATCGC }\end{array}$ & 121 & 58 \\
\hline
\end{tabular}

manufacturer's instructions (Vasu et al. 2014b). Absorbance was read at $548 \mathrm{~nm}$ using microplate reader (Molecular Devices, Sunnyvale, CA, USA).

\section{Statistical analysis}

Results were analysed using GraphPad PRISM Software (version 3.0) and presented as mean \pm s.E.M. Statistical analyses were carried out by one-way ANOVA with Bonferroni post hoc test or student's $t$-test (non-parametric) wherever applicable. For determination of lethal dose 50 (LD $\left.\mathrm{L}_{50}\right)$, XY graph $(\mathrm{X}-\log$ (concentration) vs Y (values)) was plotted in GraphPad PRISM and concentration which caused $50 \%$ reduction in viability was computed using linear/non-linear regression curve. The results were considered significant if $P<0.05$.

\section{Results}

Effect of multiple low-dose streptozotocin on islet and intestinal L-cells

Multiple low dose of streptozotocin induced severe diabetes (blood glucose $>20 \mathrm{mmol} / \mathrm{l}$ ), associated with

Published by Bioscientifica Ltd. 


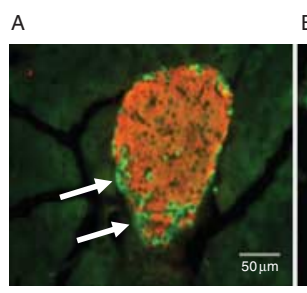

B
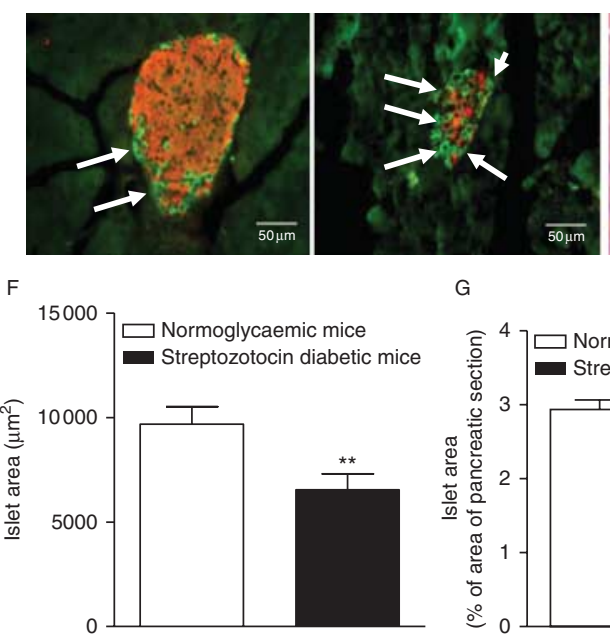

G

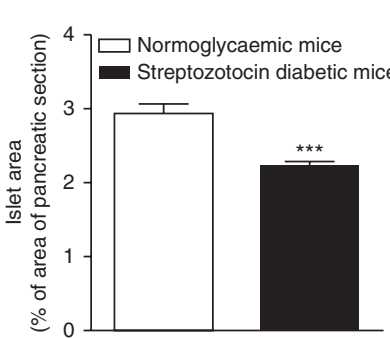

$\mathrm{D}$

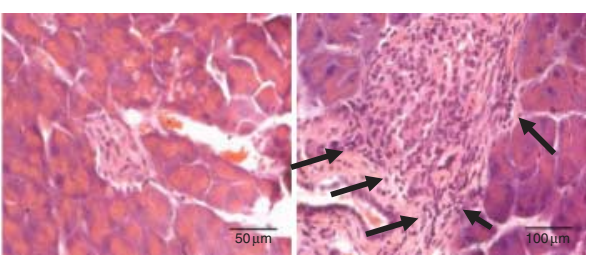

$\mathrm{H}$

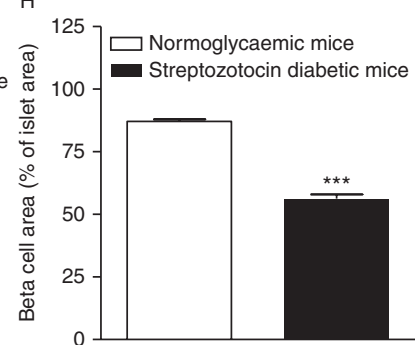

E

\begin{tabular}{|l|l|l|}
\hline Parameter & $\begin{array}{c}\text { Normoglycaemic } \\
\text { mice }\end{array}$ & $\begin{array}{c}\text { Streptozotocin } \\
\text { diabetic mice }\end{array}$ \\
\hline $\begin{array}{l}\beta \text {-cell } \\
\text { area }\left(\mu \mathrm{m}^{2}\right)\end{array}$ & $8613 \pm 776$ & $3841 \pm 506^{\star \star \star}$ \\
\hline $\begin{array}{l}\alpha \text {-cell } \\
\text { area }\left(\mu \mathrm{m}^{2}\right)\end{array}$ & $1069 \pm 88$ & $2706 \pm 285^{\star \star \star}$ \\
\hline
\end{tabular}

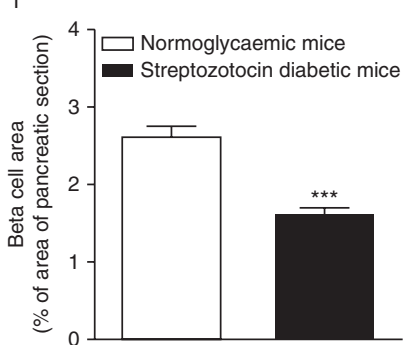

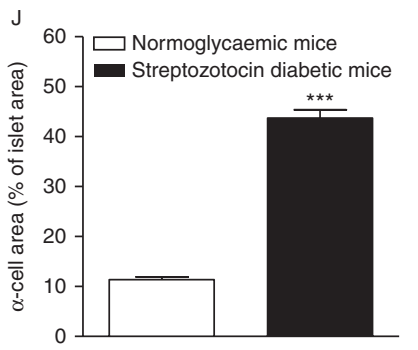

$\mathrm{K}$
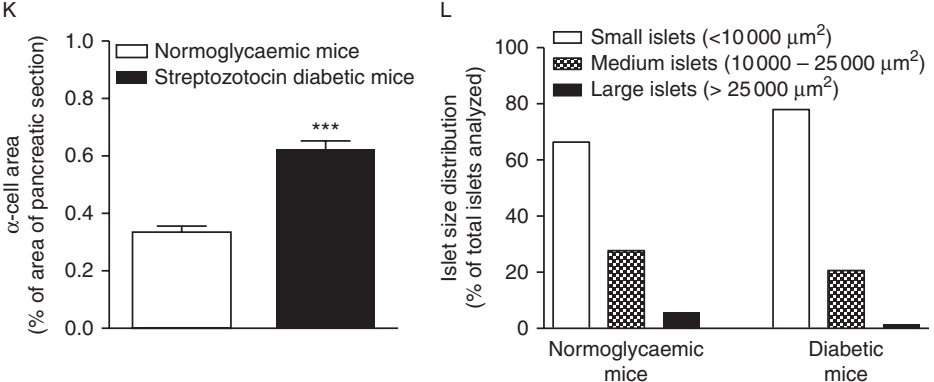

\section{Figure 1}

( $A$ and $B$ ) Representative images showing insulin (red) and glucagon (green)-positive cells and ( $C$ and $D$ ) lymphocyte infiltration in islets of normoglycaemic (A and C) and streptozotocin-induced (B and D) diabetic mice. Arrows in islets indicate glucagon-positive cells ( $A$ and $B$ ) and lymphocyte infiltration (D). (E) $\beta$ - and $\alpha$-cell area, expressed as $\mu \mathrm{m}^{2}$. (F) Islet area, expressed as $\mu \mathrm{m}^{2}$. (G) Islet area, expressed as \% of area of pancreatic section. (H) $\beta$-cell area, expressed as \% of islet area. (I) $\beta$-cell area, expressed

lymphocytic infiltration of islets and $\beta$-cell destruction. Representative images showing insulin (red) and glucagon (green) staining and lymphocyte infiltration of control and streptzotocin-treated mice are shown in Fig. 1A, B, C, and $\mathrm{D}$. Islet area and $\beta$-cell area were significantly reduced by streptozotocin treatment, while $\alpha$-cell area increased markedly $(P<0.01, P<0.001$, Fig. $1 \mathrm{E}, \mathrm{F}, \mathrm{G}, \mathrm{H}$, and $\mathrm{I})$. Percentage of islet area and total area of pancreas section occupied by $\alpha$-cells significantly increased from 12 to $43 \%$ and 0.34 to $0.63 \%$ respectively ( $P<0.001$, Fig. $1 \mathrm{~J}$ and $\mathrm{K}$ ). Islet size distribution was not affected by streptozotocin treatment (Fig. 1L). After streptozotocin treatment, lymphocyte infiltration was observed in $\sim 79 \%$ of islets.

Representative images showing Ki67 (green) and glucagon (red) staining of control and streptozotocintreated mice are shown in Fig. 2A. $\alpha$-cell proliferation was undetectable in normal mice while proliferation as \% of area of pancreatic section. (J) $\alpha$-cell area, expressed as $\%$ of islet area. (K) $\alpha$-cell area, expressed as $\%$ of area of pancreatic section. (L) Islet size distribution, expressed as $\%$ of all islets analysed. Values are mean \pm S.E.M. ( $n=6$ mice). ${ }^{*} P<0.01$ and $* * * P<0.001$ compared with normoglycaemic mie. A full colour version of this figure is available at http://dx.doi. org/10.1530/JME-14-0214.

frequency was $\sim 6 \%$ in streptozotocin-treated mice (Fig. 2B). Representative images showing haematoxylin/ eosin staining and GLP1-positive cells in the intestine of control and streptozotocin-treated mice are shown in Fig. 3A. Streptozotocin treatment did not induce lymphocyte infiltration in intestine (Fig. 3A). Intestinal L-cell count was significantly reduced by $65 \%$ fold by streptozotocin administration $(P<0.01$, Fig. 3B).

Effects of streptozotocin and cytokines on clonal insulin, glucagon and GLP1-producing cells

Basal gene expression Basal levels of Slc2a2 (Glut2) mRNA were significantly lower in $\alpha$-TC1 and GLUTag cells $(P<0.05, P<0.01$, Table 2$)$. mRNA expression of prohormone-processing enzymes coded by Pcsk1 and Pcsk2 was appreciably lower in $\alpha$-TC1 and GLUTag cells compared

Published by Bioscientifica Ltd. 
A
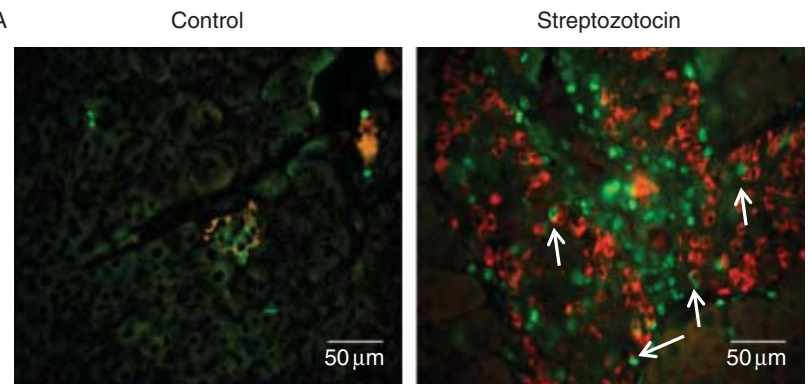

B

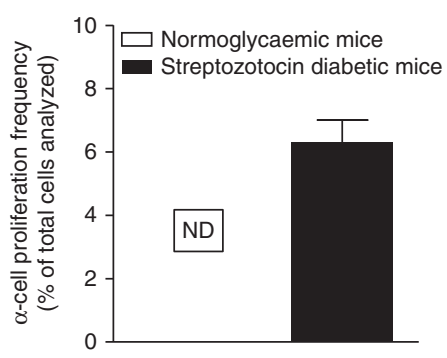

Figure 2

(A) Representative images showing Ki67 (green) and glucagon (red)positive cells in islets of normoglycaemic and streptozotocin-induced diabetic mice. Arrows indicate Ki67-positive glucagon-positive cells. (B) $\alpha$-cell proliferation frequency, expressed as $\%$ of total cells analysed. Values are mean \pm s.E.M. ( $n=6$ mice). Approximately 1500 cells were analysed. ND, none detected. A full colour version of this figure is available at http://dx.doi.org/10.1530/JME-14-0214.

with MIN6 cells $(P<0.05$, Table 2$)$. Gcg mRNA levels were significantly lower in GLUTag cells when compared with $\alpha$-TC1 cells $(P<0.01$, Table 2$)$. mRNA expression of antioxidant enzymes coded by Gpx1, Sod1, and Sod2 was similar in all three cell lines. However, mRNA expression of Cat was four- and 2.4-fold higher in $\alpha$-TC1 and GLUTag cells respectively compared with MIN6 cells $(P<0.01$, $P<0.001$, Table 2). Bcl2 transcription was significantly lower while Bax transcription was higher in GLUTag cells when compared with MIN6 cells $(P<0.05, P<0.001$, Table 2). NfkB1 mRNA levels were lower in $\alpha$-TC1 and GLUTag cells $(P<0.05, P<0.01$, Table 2$)$. Nos 2 was not expressed in healthy MIN6, $\alpha$-TC1 and GLUTag cells. Hspa5 expression was significantly lower in $\alpha$-TC1 and GLUTag cells $(P<0.05$, Table 2$)$. Il1r1 expression was significantly higher in GLUTag cells when compared with MIN6 cells $(P<0.001$, Table 2$)$. Tnfrsf1a expression was markedly lower in GLUTag cells when compared with MIN6 cells $(P<0.001$, Table 2$)$.

Cellular viability Streptozotocin and cytokines caused a dose-dependent decrease in cell viability in all three cell lines. $\mathrm{LD}_{50}$ for streptozotocin toxicity for MIN6,
$\alpha$-TC1 and GLUTag cells was $3.5,11.5$ and $4.5 \mathrm{mM}$ respectively, with $L_{50}$ for $\alpha$-TC1 cells significantly higher than MIN6 cells and GLUTag cells $(P<0.01, P<0.001$, Fig. $4 \mathrm{~A}$ ). $\mathrm{LD}_{50}$ for IL1 $\beta$ was markedly higher for $\alpha$-TC1 cells compared with MIN6 and GLUTag cells $(P<0.001$, Fig. 4B). IFN $\gamma$ caused similar levels of cell death in all three cell lines while $\mathrm{LD}_{50}$ for $\mathrm{TNF} \alpha$ was significantly higher for $\alpha$-TC1 cells than MIN6 and GLUTag cells $(P<0.01$, Fig. $4 \mathrm{C}$ and D). Cytokine cocktail containing approximately one-tenth of effective concentrations of individual cytokines caused similar levels of cell death in all three cell lines (Fig. 4E). For $\alpha$-TC1 cells, the cytokine cocktail contained higher concentrations of cytokines when compared with MIN6 and GLUTag cells, which could be attributed to enhanced protection from cytotoxicity.
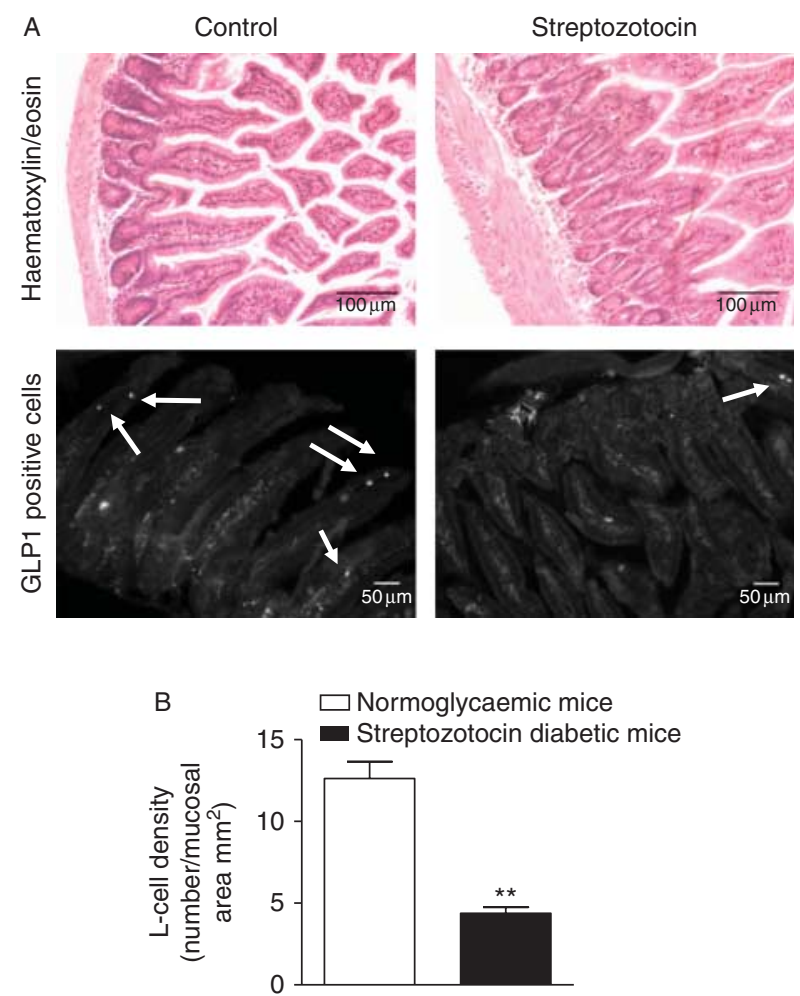

Figure 3

(A) Representative images showing haematoxylin/eosin staining and GLP1 staining in intestine of normoglycaemic and streptozotocin-induced diabetic mice. Arrows indicate GLP1-positive cells in intestine.

(B) GLP1-positive cell number, expressed as number per mucosal area $\left(\mu \mathrm{m}^{2}\right)$. GLP1-positive cells in small intestine were counted in a blinded fashion. Values are mean \pm s.E.M. $(n=6$ mice, four tissue sections at ten sections apart). ${ }^{*} P<0.01$ compared with normoglycaemic mice. A full colour version of this figure is available at http://dx.doi.org/10.1530/ JME-14-0214.

Published by Bioscientifica Ltd. 
Table 2 Comparison of gene expression profile between MIN6, $\alpha$-TC1 clone 9 and GLUTag cells. Gene expression was normalised to Actb expression, with MIN6 cells or $\alpha$-TC1 clone 9 cells as control (100\%). Values are mean \pm s.E.M. $(n=3)$

\begin{tabular}{|c|c|c|c|}
\hline Gene & MIN6 (\%) & $\begin{array}{c}\alpha \text {-TC1 clone } 9 \\
(\%)\end{array}$ & GLUTag (\%) \\
\hline \multicolumn{4}{|c|}{ Secretory function } \\
\hline Ins & $100 \pm 2$ & NA & NA \\
\hline Gcg & NA & $100 \pm 6$ & $6 \pm 12^{\dagger}$ \\
\hline S/c2a2 & $100 \pm 10$ & $3 \pm 19 *$ & $21 \pm 10^{\dagger}$ \\
\hline Pcsk1 & $100 \pm 12$ & $0.3 \pm 10^{\dagger}$ & $12 \pm 6^{\dagger}$ \\
\hline Pcsk2 & $100 \pm 9$ & $12 \pm 10^{\dagger}$ & $7 \pm 7^{\dagger}$ \\
\hline \multicolumn{4}{|c|}{ Antioxidant defence } \\
\hline Cat & $100 \pm 20$ & $400 \pm 5^{\ddagger}$ & $242 \pm 5^{\dagger}$ \\
\hline Gpx1 & $100 \pm 12$ & $103 \pm 5$ & $80 \pm 6$ \\
\hline Sod1 & $100 \pm 8$ & $112 \pm 6$ & $72 \pm 12$ \\
\hline Sod2 & $100 \pm 15$ & $72 \pm 10$ & $93 \pm 9$ \\
\hline \multicolumn{4}{|l|}{ Apoptosis } \\
\hline Bax & $100 \pm 15$ & $144 \pm 8$ & $157 \pm 7^{*}$ \\
\hline$B c / 2$ & $100 \pm 9$ & $74 \pm 4$ & $7 \pm 2^{\ddagger}$ \\
\hline$N f_{K} B$ & $100 \pm 7$ & $43 \pm 7^{\dagger}$ & $46 \pm 11 *$ \\
\hline Nos2 & Not expressed & Not expressed & Not expressed \\
\hline \multicolumn{4}{|l|}{ ER stress } \\
\hline Hspa4 & $100 \pm 16$ & $123 \pm 9$ & $84 \pm 7$ \\
\hline Hspa5 & $100 \pm 18$ & $11 \pm 7 *$ & $12 \pm 10 *$ \\
\hline \multicolumn{4}{|c|}{ Cytokine receptors } \\
\hline $1 / 1 r 1$ & $100 \pm 12$ & $119 \pm 14$ & $203 \pm 17^{\dagger}$ \\
\hline Ifngr1 & $100 \pm 12$ & $77 \pm 16$ & $93 \pm 19$ \\
\hline Tnfrsf1a & $100 \pm 14$ & $53 \pm 10$ & $0.52 \pm 20 *$ \\
\hline
\end{tabular}

${ }^{*} P<0.05,{ }^{\dagger} P<0.01$, and ${ }^{\ddagger} P<0.001$ compared with MIN6 or for proglucagon gene expression to $\alpha$-TC1 clone 9 cells. NA, not assessed.

Hormone secretion and associated genes Streptozotocin and cytokine cocktail significantly decreased hormone secretion from MIN6 and GLUTag cells during 8-h exposure $(P<0.05, P<0.01$, Fig. 5A and $C)$. In contrast, cytokine cocktail and streptozotocin significantly increased glucagon release from $\alpha$-TC1 cells $(P<0.001$, Fig. 5B). These effects were associated with decreased Ins transcription in MIN6 cells $(P<0.05, P<0.001$, Table 3$)$, and a downward trend in $G c g$ transcription in GLUTag cells. In $\alpha$-TC1 cells, cytokine cocktail significantly increased $G c g$ transcription while streptozotocin significantly decreased $G c g$ transcription $(P<0.05$, Table 4$)$. Streptozotocin markedly reduced Pcsk1 and Pcsk2 transcription in GLUTag cells $(P<0.05, P<0.01$, Table 3$)$. Pcsk2 transcription was also reduced in MIN6 cells $(P<0.05$, Table 3). Both streptozotocin and cytokine cocktail decreased Glut2 mRNA levels in MIN6 cells $(P<0.05$, Table 3). Cytokine cocktail significantly increased Glut2 transcription in GLUTag cells $(P<0.05$, Table 3$)$.

Genes involved in antioxidant defence mRNA expression of Cat, Gpx1 and Sod2 was upregulated in streptozotocin-treated MIN6 cells $(P<0.05, P<0.001$, Table 4). Gpx1, Sod1 and Sod2 transcription was downregulated in cytokine cocktail-treated MIN6 cells $(P<0.05, P<0.01$, Table 4$)$. In $\alpha$-TC1 cells, streptozotocin upregulated Sod2 expression, whereas cytokine cocktail decreased Cat, Gpx1 and Sod1 transcription, with positive effects on Sod2 $(P<0.001$, Table 4). In GLUTag cells, streptozotocin upregulated Cat, Sod1 and Sod2 transcription while cytokine cocktail upregulated Cat transcription $(P<0.05, P<0.01$, Table 4$)$.

Cytokine receptors Cytokine cocktail exposure significantly increased Il1r1 expression in MIN6 cells but not in $\alpha$-TC1 nor GLUTag cells $(P<0.001$, Table 4$)$. Cytokine exposure did not alter Ifngr 1 expression in any of the cell lines tested, but Tnfrsf1a expression was increased in GLUTag cells $(P<0.001$, Table 4$)$.

DNA damage All three cell lines suffered DNA damage by streptozotocin and cytokine cocktail. Streptozotocin, a DNA alkylating agent, increased \% tail DNA by four-, 2.9- and 2.7-fold and olive tail moment by 13-, 12- and eightfold in MIN6, $\alpha$-TC1 and GLUTag cells respectively $(P<0.001$, Fig. 6A and B). Cytokine cocktail increased \%
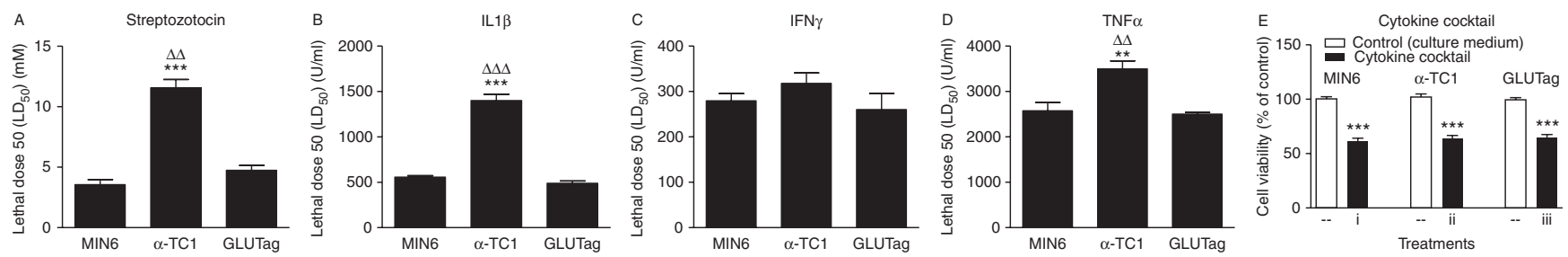

Figure 4

Lethal dose $\left(\mathrm{LD}_{50}\right)$ of streptozotocin (A), IL1 $\beta$ (B), IFN $\gamma(C)$ and TNF $\alpha$ (D). Values area mean + S.E.M. $(n=6) . * * P<0.01$ and $* * * P<0.001$ compared with MIN6 cells. ${ }^{\Delta \Delta} P<0.01$ and ${ }^{\Delta \Delta \Delta} P<0.001$ compared with GLUTag cells. (E) Cell viability (\% of control) of MIN6, $\alpha$-TC1 and GLUTag cells after 8-h exposure

to cytokine cocktail, containing i) $60 \mathrm{U} / \mathrm{ml} \mathrm{IL} 1 \beta+20 \mathrm{U} / \mathrm{ml} \mathrm{IFN} \gamma+200 \mathrm{U} / \mathrm{ml}$ TNF $\alpha$; ii) $100 \mathrm{U} / \mathrm{ml} \mathrm{IL} 1 \beta+25 \mathrm{U} / \mathrm{ml} \mathrm{IFN} \gamma+250 \mathrm{U} / \mathrm{ml} \mathrm{TNF} \alpha$; and iii) $60 \mathrm{U} / \mathrm{ml}$ $\mathrm{IL} 1 \beta+16 \mathrm{U} / \mathrm{ml}$ IFN $\gamma+185 \mathrm{U} / \mathrm{ml}$ TNF $\alpha$. Values area mean \pm s.E.M. $(n=6)$. $\star * \star P<0.001$ compared with untreated control. http://jme.endocrinology-journals.org DOI: $10.1530 / J M E-14-0214$
(C) 2015 Society for Endocrinology Printed in Great Britain 


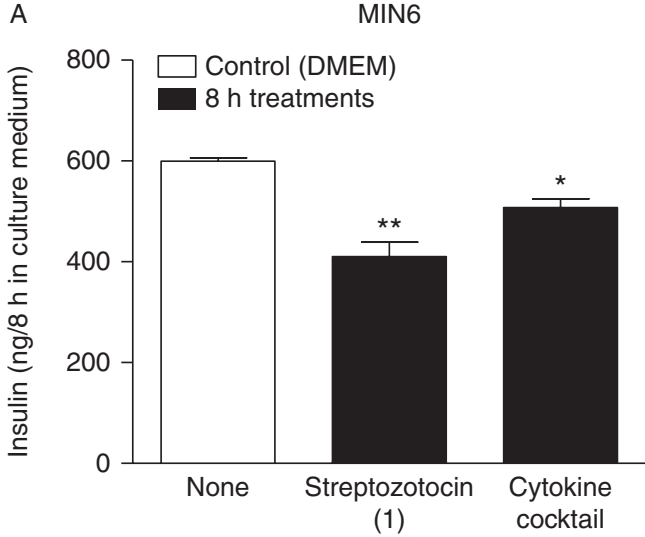

Treatments $(\mathrm{mM})$
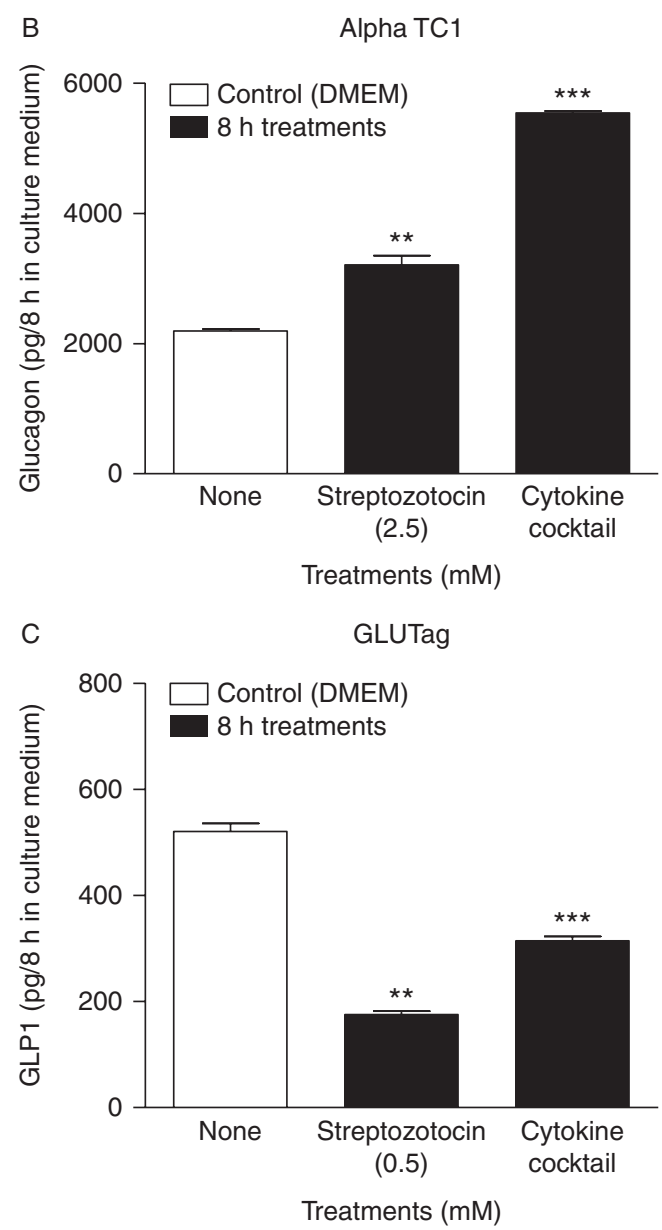

Figure 5

(A) Insulin release from MIN6 cells during 8-h exposure to streptozotocin and cytokine cocktail $(60 \mathrm{U} / \mathrm{ml} \mathrm{IL} 1 \beta+20 \mathrm{U} / \mathrm{ml} \mathrm{IFN} \gamma+200 \mathrm{U} / \mathrm{ml} \mathrm{TNF} \alpha)$. (B) Glucagon release from $\alpha$-TC1 cells during 8-h exposure to streptozotocin and cytokine cocktail $(100 \mathrm{U} / \mathrm{ml} \mathrm{IL} 1 \beta+25 \mathrm{U} / \mathrm{ml} \mathrm{IFN} \gamma+250 \mathrm{U} / \mathrm{ml}$ TNF $\alpha)$. (C) GLP1 release from GLUTag cells during 8-h exposure to streptozotocin and cytokine cocktail $(60 \mathrm{U} / \mathrm{ml} \mathrm{IL1} \beta+16 \mathrm{U} / \mathrm{ml} \mathrm{IFN} \gamma+185 \mathrm{U} / \mathrm{ml} \mathrm{TNF} \alpha)$. Values are mean \pm s.E.M. $(n=3) .{ }^{*} P<0.05, * * P<0.01$, and $* * * P<0.001$ compared with untreated control.

(c) 2015 Society for Endocrinology Printed in Great Britain tail DNA by two-, 1.2- and twofold and olive tail moment by 3.3-, three- and 3.7-fold in MIN6, $\alpha$-TC1 and GLUTag cells respectively $(P<0.001$, Fig. 6A and B). Compared with MIN6 cells, DNA damage was significantly lesser in $\alpha$-TC1 and GLUTag cells $(P<0.001$, Fig. 6A and B). Streptozotocin-induced DNA damage in GLUTag cells was significantly less than $\alpha$-TC1 cells, while cytokine-induced DNA damage was significantly higher than $\alpha$-TC1 cells $(P<0.05, P<0.01, P<0.001$, Fig. 6A and B). Toxic effects of streptozotocin and cytokines on DNA were comparable to DNA damage caused by exposure to ultraviolet light.

\section{ER stress response, apoptosis and nitrite produc-}

tion In GLUTag cells, cytokine cocktail increased Hspa4 and decreased Hspa5 transcription $(P<0.01, P<0.001$, Table 4). In contrast, streptozotocin decreased Hspa5 transcription in all three cell lines $(P<0.05, P<0.01$, Table 4). Streptozotocin and cytokine cocktail significantly reduced $\mathrm{Bcl} 2$ mRNA levels in MIN6 cells $(P<0.05$, Table 4). mRNA expression of Bax was unaffected in all three cell lines. Cytokines markedly increased $N f k B 1$ transcription in all three cell lines, which was accompanied by a substantial increase in Nos 2 transcription $(P<0.01, P<0.001$, Table 4$)$ and nitrite production (Fig. 6D). In our experiments, we considered untreated control cells with no expression of Nos2 (Table 2) as 100\% (cycle threshold value was $>35$ in PCR) and compared treated cells with this value. The percentage of apoptotic cells was significantly higher in all three cell lines after exposure to cytotoxins $(P<0.05, P<0.01, P<0.001$, Fig. 6C).

\section{Discussion}

Pancreatic $\beta$-cells are susceptible to streptozotocin and cytokine toxicity, whereas knowledge of the sensitivity of intestinal L-cells and pancreatic $\alpha$-cells to these toxins is limited (Lenzen 2008). This paper evaluates the effects of multiple low-dose streptozotocin on these cell types in C57BL/6 mice, together with studies on cellular responses and related gene expression of intestinal $\mathrm{L}$-cell and pancreatic $\beta$-, $\alpha$-cell models under defined cytotoxic conditions in vitro.

Repeated injection of low sub-diabetogenic doses of streptozotocin over 5 days induced a severe form of diabetes (blood glucose $>20 \mathrm{mmol} / \mathrm{l}$ ) associated with lymphocytic infiltration of islets and $\beta$-cell destruction as is well known for this model (Shehata et al. 2011). Thus unlike a single large dose of streptozotocin that induces DNA damage and lethal depletion of NAD following DNA

Published by Bioscientifica Ltd 
Table 3 mRNA expression of genes involved in secretory function in MIN6, $\alpha$-TC1 clone 9 and GLUTag cells after exposure to streptozotocin and cytokine cocktail. Gene expression was normalised to Actb expression, with respective untreated cells as control $(100 \%)$. Values are mean \pm s.E.M. $(n=3)$

\begin{tabular}{|c|c|c|c|c|}
\hline Gene & Cell line & Control & Streptozotocin & $\begin{array}{l}\text { Cytokine } \\
\text { cocktail }\end{array}$ \\
\hline Ins & MIN6 & $100 \pm 2.4$ & $67 \pm 8^{*}$ & $40 \pm 5^{\ddagger}$ \\
\hline \multirow[t]{2}{*}{ Gcg } & $\alpha$-TC1 clone 9 & $100 \pm 6.9$ & $65 \pm 10$ * & $137 \pm 5^{*}$ \\
\hline & GLUTag & $100 \pm 12$ & $63 \pm 11$ & $82 \pm 6$ \\
\hline \multirow[t]{3}{*}{ Glut2 } & MIN6 & $100 \pm 10$ & $38.7 \pm 9 *$ & $45 \pm 6 *$ \\
\hline & $\alpha$-TC1 clone 9 & $100 \pm 20$ & $77 \pm 20$ & $114 \pm 6$ \\
\hline & GLUTag & $100 \pm 38$ & $57 \pm 16$ & $226 \pm 15^{*}$ \\
\hline \multirow[t]{3}{*}{ Pcsk1 } & MIN6 & $100 \pm 13$ & $72 \pm 12$ & $113 \pm 9$ \\
\hline & $\alpha$-TC1 clone 9 & $100 \pm 11$ & $73 \pm 9$ & $112 \pm 9$ \\
\hline & GLUTag & $100 \pm 6$ & $45 \pm 9^{\dagger}$ & $91 \pm 8$ \\
\hline \multirow[t]{3}{*}{ Pcsk2 } & MIN6 & $100 \pm 9$ & $50 \pm 5 *$ & $84 \pm 6$ \\
\hline & $\alpha$-TC1 clone 9 & $100 \pm 11$ & $86 \pm 8$ & $123 \pm 9$ \\
\hline & GLUTag & $100 \pm 7$ & $59 \pm 9 *$ & $82 \pm 9$ \\
\hline
\end{tabular}

${ }^{*} P<0.05,{ }^{\dagger} P<0.01$, and ${ }^{\ddagger} P<0.001$ compared with control.

repair in $\beta$-cells (Lenzen 2008), cytotoxic effects in this model are likely to involve both chemical and cellmediated cytokine-induced attack (Sternesjo et al. 1997, Shehata et al. 2011). Lymphocyte infiltration was observed in $\sim 79 \%$ of total islets analysed. Such effects were associated with reductions in both islet and $\beta$-cell areas, whereas $\alpha$-cell area was increased, reflecting resistance of glucagon secreting cells to cytotoxicity as well as observed increase in $\alpha$-cell proliferation. Destruction of $\beta$-cells with loss of normal paracrine inhibition by insulin may also contribute in this regard (Kelly et al. 2011).

Interestingly, multiple low-dose streptozotocin reduced the numbers of GLP1 secreting cells in the small intestine without any apparent induction of lymphocyte infiltration, suggesting induction of L-cell death, including possible deleterious effects on precursor stem cells that arise from within villus crypts (Gribble 2012). This apparent difference between $\alpha$ - and L-cells is notable given that both express the proglucagon gene and originate from similar cell lineage (Baggio \& Drucker 2007). The turnover of intestinal L-cells is $\sim 5$ days and hence a reduction in L-cell number per $\mathrm{mm}^{2}$ mucosal area, 5 days after the last streptozotocin administration might also relate to diabetic status of the animals and not to streptozotocin toxicity. In an independent study with similar experimental design, we observed that multiple low-dose streptozotocin treatment increased pancreatic and plasma glucagon, reduced pancreatic and plasma insulin while increasing plasma GLP1 (Vasu et al. 2014a). Such an increase in circulating GLP1 could be due to islet $\alpha$-cell-derived GLP1 in conditions of stress (Vasu etal. 2014a). Thus, many recent studies including our own have shown significant production of GLP1 by islet $\alpha$-cells under conditions of stress. To investigate these issues in more detail, GLUTag and MIN6, $\alpha$-TC1 cells, were used to examine cellular responses and expression of genes determining susceptibility to such cytotoxic insults.

Individual cytokines (IL1 $\beta$, IFN $\gamma, \mathrm{TNF} \alpha$ ) and streptozotocin decreased cell viability in all three cell lines in a dose-dependent fashion, an effect which has been documented previously in $\beta$-cells (Gao et al. 2000, Andersson et al. 2001, Eizirik et al. 2003, Kharroubi et al. 2004, Zhang et al. 2007). The $\mathrm{LD}_{50}$ values for these agents were not significantly different for MIN6 and GLUTag cells, but they were 1.3- to 3.2-fold greater in $\alpha$-TC1 cells exposed to streptozotocin, IL1 $\beta$ or TNF $\alpha$. The relative resistance of $\alpha$-TC1 cells to IL1 $\beta$ toxicity is consistent with previous observations (Hamaguchi \& Leiter 1990). We also observed similar levels of cytokine receptor expression in MIN6 and $\alpha$-TC1 cells. Thus resistance of $\alpha$-cells to cytokine toxicity may be attributed to enhanced defence mechanisms and not due to differences in cytokine receptor expression. As streptozotocin mimics glucose in structure and enters cells via Glut2 transporter (Elsner $e$ t al. 2000, 2008, Lenzen 2008), lower Glut2 mRNA levels in $\alpha$-TC1 may contribute to the streptozotocin resistance.

Interestingly, GLUTag cells also expressed very low levels of Glut2 mRNA compared with MIN6 cells, suggesting the involvement in L-cells of other glucose transporter isoforms or more likely the SGLT1 transporter (Gribble et al. 2003) in cellular uptake and action of streptozotocin. In vivo, the observed decrease in L-cell numbers could be due to direct toxic action of streptozotocin plus accompanying glucose toxicity as there was no evidence of intestinal lymphocyte infiltration. However, our in vitro observations indicate susceptibility of L-cells to cytokines and thus elevated concentrations of pro-inflammatory cytokines and glucose observed in circulation in type 1 diabetes (Lechleitner et al. 2000, Hanifi-Moghaddam et al. 2003, Chatzigeorgiou et al. 2010) could affect L-cell function and survival. Elevated level of $\mathrm{TNF} \alpha$ after a single high-dose streptozotocin treatment has been reported recently (Ho et al. 2014), but further investigations are required to assess cytokine levels after multiple low-dose streptozotocin treatment. Concentrations used in our study were similar to other investigations on cytokine toxicity, while concentrations in the cytokine cocktail were slightly higher than those observed in the plasma of type 1 diabetic patients (Chatzigeorgiou et al. 2010). In vivo and in vitro conditions are different

Published by Bioscientifica Ltd. 
Table 4 mRNA expression of genes involved in stress response in MIN6, $\alpha$-TC1 and GLUTag cells after exposure to streptozotocin or cytokine cocktail. Gene expression was normalised to Actb expression, with respective untreated cells as control (100\%). Values are mean \pm S.E.M. $(n=3)$

\begin{tabular}{|c|c|c|c|c|}
\hline Gene & Cell line & Control & Streptozotocin & Cytokine cocktail \\
\hline \multicolumn{5}{|c|}{ Antioxidant defence } \\
\hline \multirow[t]{3}{*}{ Cat } & MIN6 & $100 \pm 12$ & $284 \pm 14^{\ddagger}$ & $86 \pm 11$ \\
\hline & $\alpha$-TC1 clone 9 & $100 \pm 6$ & $111 \pm 7$ & $15 \pm 7^{\ddagger}$ \\
\hline & GLUTag & $100 \pm 16$ & $155 \pm 10 *$ & $198 \pm 13^{\dagger}$ \\
\hline \multirow[t]{3}{*}{ Gpx1 } & MIN6 & $100 \pm 6$ & $147 \pm 12^{*}$ & $45 \pm 4^{\dagger}$ \\
\hline & $\alpha$-TC1 clone 9 & $100 \pm 5$ & $100 \pm 6$ & $19 \pm 8^{\dagger}$ \\
\hline & GLUTag & $100 \pm 9$ & $133 \pm 10$ & $98 \pm 6$ \\
\hline \multirow[t]{3}{*}{ Sod1 } & MIN6 & $100 \pm 9$ & $91 \pm 12$ & $33 \pm 4^{\dagger}$ \\
\hline & $\alpha$-TC1 clone 9 & $100 \pm 7$ & $85 \pm 10$ & $67 \pm 8 *$ \\
\hline & GLUTag & $100 \pm 14$ & $162 \pm 11 *$ & $117 \pm 10$ \\
\hline \multirow[t]{3}{*}{ Sod2 } & MIN6 & $100 \pm 3$ & $164 \pm 3^{\ddagger}$ & $44 \pm 3^{\ddagger}$ \\
\hline & $\alpha$-TC1 clone 9 & $100 \pm 11$ & $134 \pm 5^{*}$ & $157 \pm 9^{\ddagger}$ \\
\hline & GLUTag & $100 \pm 10$ & $146 \pm 5^{*}$ & $83 \pm 10$ \\
\hline \multicolumn{5}{|l|}{ Apoptosis } \\
\hline \multirow[t]{3}{*}{ Bax } & MIN6 & $100 \pm 9$ & $105 \pm 7$ & $100 \pm 12$ \\
\hline & $\alpha$-TC1 clone 9 & $100 \pm 9$ & $79 \pm 10$ & $81 \pm 9$ \\
\hline & GLUTag & $100 \pm 7$ & $96 \pm 10$ & $81 \pm 8$ \\
\hline \multirow[t]{3}{*}{$B c / 2$} & MIN6 & $100 \pm 9$ & $55 \pm 10 *$ & $57 \pm 9 *$ \\
\hline & $\alpha$-TC1 clone 9 & $100 \pm 4$ & $75 \pm 8$ & $76 \pm 8$ \\
\hline & GLUTag & $100 \pm 6$ & $96 \pm 9$ & $97 \pm 6$ \\
\hline \multirow[t]{3}{*}{$N f k B 1$} & MIN6 & $100 \pm 10$ & $102 \pm 7$ & $223 \pm 9^{\ddagger}$ \\
\hline & $\alpha$-TC1 clone 9 & $100 \pm 7$ & $140 \pm 8 *$ & $185 \pm 10^{\dagger}$ \\
\hline & GLUTag & $100 \pm 6$ & $90 \pm 9$ & $270 \pm 6^{\ddagger}$ \\
\hline \multirow[t]{3}{*}{ Nos2 } & MIN6 & $100 \pm 6$ & $92 \pm 9$ & $658 \pm 22^{\ddagger}$ \\
\hline & $\alpha$-TC1 clone 9 & $100 \pm 9$ & $58 \pm 9 *$ & $7084 \pm 12^{\ddagger}$ \\
\hline & GLUTag & $100 \pm 7$ & $139 \pm 11$ * & $485 \pm 10^{\ddagger}$ \\
\hline \multicolumn{5}{|c|}{ ER stress response } \\
\hline \multirow[t]{3}{*}{ Hspa4 } & MIN6 & $100 \pm 9$ & $76 \pm 8$ & $89 \pm 8$ \\
\hline & $\alpha$-TC1 clone 9 & $100 \pm 9$ & $70 \pm 8$ & $102 \pm 7$ \\
\hline & GLUTag & $100 \pm 7$ & $115 \pm 9$ & $197 \pm 7^{\ddagger}$ \\
\hline \multirow[t]{3}{*}{ Hspa5 } & MIN6 & $100 \pm 12$ & $31 \pm 8^{\dagger}$ & $62 \pm 13$ \\
\hline & $\alpha$-TC1 clone 9 & $100 \pm 7$ & $73 \pm 5 *$ & $14 \pm 9^{\dagger}$ \\
\hline & GLUTag & $100 \pm 10$ & $50 \pm 9 *$ & $118 \pm 6$ \\
\hline \multicolumn{5}{|c|}{ Cytokine receptors } \\
\hline \multirow[t]{3}{*}{$\| / 1 r 1$} & MIN6 & $100 \pm 24$ & NA & $960 \pm 38^{\ddagger}$ \\
\hline & $\alpha$-TC1 clone 9 & $100 \pm 14$ & NA & $173 \pm 31$ \\
\hline & GLUTag & $100 \pm 29$ & NA & $172 \pm 8$ \\
\hline \multirow[t]{3}{*}{ Ifngr1 } & MIN6 & $100 \pm 12$ & NA & $97 \pm 35$ \\
\hline & $\alpha$-TC1 clone 9 & $100 \pm 16$ & NA & $161 \pm 18$ \\
\hline & GLUTag & $100 \pm 27$ & NA & $91 \pm 8$ \\
\hline \multirow[t]{3}{*}{ Tnfrsf1a } & MIN6 & $100 \pm 21$ & NA & $133 \pm 19$ \\
\hline & $\alpha$-TC1 clone 9 & $100 \pm 10$ & NA & $107 \pm 19$ \\
\hline & GLUTag & $100 \pm 20$ & NA & $656 \pm 29^{\ddagger}$ \\
\hline
\end{tabular}

${ }^{*} P<0.05,{ }^{\dagger} P<0.01$, and ${ }^{\ddagger} P<0.001$ compared with control. NA, not assessed.

as autoimmune cells, in addition to pro-inflammatory cytokines, release other factors including nitric oxide, granzymes and perforins, which have synergistic effects, thus explaining the choice of concentrations in our study. Further investigations into the actions of cytokines were examined using cocktails containing approximately one-tenth of $\mathrm{LD}_{50}$ dose of individual cytokines, thereby ensuring comparable reduction in viability of each cell line. As $\alpha$-TC1 cells were relatively resistant to streptozotocin, lower concentrations (which were lethal for MIN6 and GLUTag cells) may not induce any cellular responses. Hence we chose to test individual concentrations at which a significant reduction in viability of each cell line was observed.

The cellular actions of streptozotocin and cytokine cocktail were accompanied by decreased release of insulin and GLP1 during 8-h cultures of MIN6 and GLUTag cells, whereas glucagon release was enhanced from $\alpha$-TC1 cells.

Published by Bioscientifica Ltd. 
A
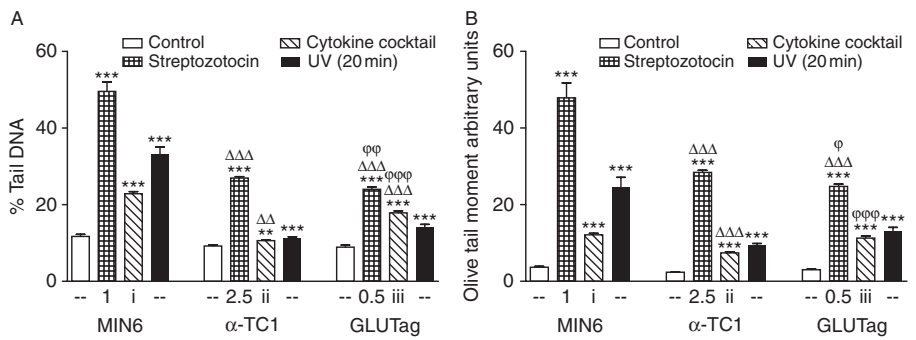

C

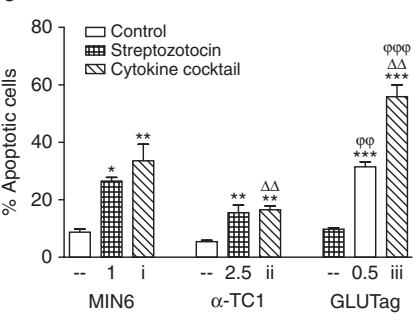

D

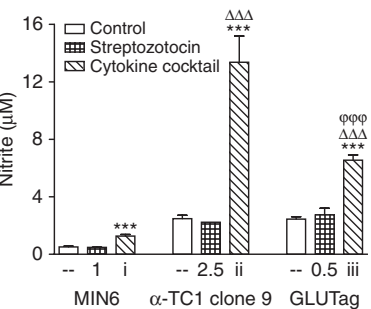

Figure 6

Effects of 8-h exposure of MIN6, $\alpha$-TC1 clone 9 and GLUTag cells to streptozotocin and cytokine cocktail on (A) \% tail DNA in comets, (B) olive tail moment of comets, (C) \% apoptotic cells and (D) nitrite accumulation in culture medium. Cytokine cocktail consisted of i) $60 \mathrm{U} / \mathrm{ml} \mathrm{IL1} \beta+20 \mathrm{U} / \mathrm{ml}$ IFN $\gamma+200 \mathrm{U} / \mathrm{ml} \mathrm{TNF} \alpha$; ii) $100 \mathrm{U} / \mathrm{ml} \mathrm{IL} 1 \beta+25 \mathrm{U} / \mathrm{ml} \mathrm{IFN} \gamma+250 \mathrm{U} / \mathrm{ml} \mathrm{TNF} \alpha$; and iii) $60 \mathrm{U} / \mathrm{ml} \mathrm{IL1} \beta+16 \mathrm{U} / \mathrm{ml} \mathrm{IFN} \gamma+185 \mathrm{U} / \mathrm{ml}$ TNF $\alpha$. Values are mean \pm s.E.M. $(n=4)$. Approximately 100 cells per replicate were analysed for comet assay and acridine orange/ethidium bromide assay. ${ }^{*} P<0.05, * * P<0.01$, and ${ }^{* * *} P<0.001$ compared with untreated control. ${ }^{\Delta \Delta} P<0.01$ and ${ }^{\Delta \Delta \Delta} P<0.001$ compared with respective treatment of MIN6 cells. ${ }^{\varphi} P<0.05,{ }^{\varphi \varphi} P<0.01$, ${ }^{\varphi \varphi \varphi} P<0.001$ compared with respective treatment of $\alpha$-TC1 cells.
With exception of $\alpha$-TC1 cells exposed to cytokines, cytotoxins decreased Ins and Gcg gene expression which undoubtedly contributed to decreased hormone output. Other contributing factors might be changes in proglucagon processing or damage to proteins such as those involved in granule transport and exocytosis. Indeed, streptozotocin markedly decreased Pcsk2 transcription in MIN6 cells and Pcsk1 and Pcsk2 transcription in GLUTag cells but not in $\alpha$-TC1 cells. Cytokines did not markedly affect transcription of prohormone convertases in any of the cell lines, but a trend towards downregulation of Pcsk2 was observed in MIN6 and GLUTag cells. This difference clearly reflects different mechanisms of action which for cytokines involves activation of master transcription factors - NFkB and STAT1, resulting in transactivation of a number of genes involved in function and cell survival (Gurzov et al. 2008, Moore et al. 2012).

The high susceptibility of insulin secreting cells to streptozotocin and other toxins, such as alloxan, is partly attributed to poor antioxidant defence mechanisms, including low levels of catalase, superoxide dismutase and glutathione peroxidase (Lenzen 2008). In this study, cytokines decreased transcription of Gpx1, Sod1 and Sod2 in MIN6 cells and Gpx1, Cat and Sod1 in $\alpha$-TC1 cells but upregulated Cat transcription in GLUTag cells. Streptozotocin upregulated transcription of Gpx1, Cat and Sod1 in MIN6 cells; Cat, Sod1 and Sod2 in GLUTag cells and Sod2 in $\alpha$-TC1 cells, representing activation of defence mechanisms to counter cytotoxic attack. Oxidative stress activates $N f_{\kappa} B$, a rapid acting transcription factor which activates either defence mechanisms via Sod2 upregulation or apoptosis via Bax upregulation among other effects. We did not observe Sod2 upregulation in cytokine cocktail-treated MIN6 and GLUTag cells which could be due to the fact that $N f_{\kappa} B$ activation activates apoptosis pathways instead of cellular defence pathways in these cell types. Upregulation of Sod 2 in $\alpha$-TC1 cells together with higher expression of Cat mRNA compared with MIN6 cells could offer protection from oxidative stress. In line with our observations, higher level of catalase enzyme expression was observed in pancreatic $\alpha$-cells previously (Bloch et al. 2007).

Cytokine cocktail increased $N f_{\kappa} b 1$ transcription in all cell lines, which was accompanied by strong induction of Nos2 expression and a significant increase in nitrite levels in the culture medium as observed previously in cytokine-exposed $\beta$-cell models, human islets and FACSpurified rat $\beta$-cells (Corbett et al. 1993, Lortz et al. 2000, Lakey et al. 2001, Sigfrid et al. 2003, Souza et al. 2004, Larsen et al. 2007, Zhang et al. 2007, Gurzov et al. 2008, Moore et al. 2011, 2012). Although gene expression data does not reflect activity of $\mathrm{NF} \kappa \mathrm{B}$, it should be noted that $\mathrm{NF} \kappa \mathrm{B}$ autoregulates its own expression. Thus increase in $N f_{k} b 1$ transcription indirectly suggests enhanced activity after cytokine exposure. Streptozotocin also upregulated $N f_{\kappa} B$ in $\alpha$-TC1 cells but decreased Nos 2 expression without affecting nitrite production. Nos2 was not expressed to any significant extent in healthy MIN6, $\alpha$-TC1 or GLUTag cells. Nitrite interferes with ER $\mathrm{Ca}^{2+}$ homeostasis and activates the ER stress response which together with oxidative stress results in upregulation of expression of molecular chaperones. Hspa4 transcription was noticeably increased in cytokine cocktail-treated GLUTag cells, suggesting the activation of ER stress response or existence of oxidative stress. Further, cytokine exposure increased transcription of cytokine

Published by Bioscientifica Ltd. 
receptors in MIN6 and GLUTag cells ( $\alpha$-TC1 cells to some extent), suggesting the activation of master transcription factors STAT1 and NFkB which activate transcription of cytokine receptors among other genes.

Consistent with different pattern of gene expression and susceptibility to cytotoxic attack, the level of DNA damage was modest in $\alpha$-TC1 cells treated with toxins when compared with MIN6 or GLUTag cells. Excessive DNA damage activates mitochondrial apoptotic pathway and explains the observed downregulation of $\mathrm{Bcl} 2$ transcription and increased numbers of apoptotic MIN6 cells. Although we used different concentrations of streptozotocin and cytokine cocktail for all three cell lines, lower degree of DNA damage even at higher concentration clearly suggests enhanced protection from cytotoxicity in $\alpha$-TC1 cells. Induction of apoptosis was also of greater magnitude in MIN6 and GLUTag cells compared with $\alpha$-TC1 cells. The cells in small intestine express lower levels of $\mathrm{Bcl} 2$ and undergo spontaneous apoptosis due to lower threshold for induction of apoptosis, further confirming our observations (Potten 1992, Bach et al. 2000). Additional investigations using same concentrations of cytokines or streptozotocin would be useful to compare absolute differences in susceptibility of pancreatic $\alpha-, \beta$ - and intestinal L-cells to cytotoxicity.

In conclusion, streptozotocin and cytokines impaired secretory function, activated anti-oxidant defence mechanisms, induced DNA damage, reduced cell viability and triggered apoptosis in both GLUTag and MIN6 cells. In comparison, $\alpha$-TC1 cells were substantially less susceptible to both streptozotocin and cytokines-evoked attack due to differences in the expression of genes involved in mediating their toxicity or anti-oxidant defence mechanisms. Additional studies evaluating gene expression at protein level would extend these data, but the present observations help to explain selective loss of $\beta$-cells in diabetes together with proliferation and enhanced function of glucagon secreting $\alpha$-cells. Our data also suggest that GLP1-secreting L-cells are prone to cytotoxic attack and dysfunctional secretion, although this may be limited in vivo due to the rapid cell turnover of the intestinal mucosa and cellular replacement by differentiating stem cells that arise from the intestinal crypt (Roth et al. 1990, Bach et al. 2000, Schonhoff et al. 2004, Cani et al. 2007). Similar to $\beta$-cell compensation during early stages of diabetes and exhaustion in later stages, L-cell compensation may well precede L-cell exhaustion which in turn may further contribute to disease progression. Further investigations to assess the effects of chronic elevation of cytokines in circulation on enteroendocrine cells could help to better understand the observed metabolic abnormalities in type 1 diabetes.

\section{Declaration of interest}

The authors declare that there is no conflict of interest that could be perceived as prejudicing the impartiality of the research reported.

\section{Funding}

The study was supported by University of Ulster selective research funding, SAAD donation, Vice Chancellor's Research Scholarship (S V) and Department of Employment and Learning Research Scholarship (R C M).

\section{Author contribution statement}

S V and R C M contributed to acquisition of data, analysis, interpretation and drafted the manuscript. P R F and $\mathrm{N} \mathrm{H} \mathrm{M}$ conceived and designed the study and revised the manuscript critically for intellectual content. All authors approved the final version.

\section{References}

Andersson AK, Flodstrom M \& Sandler S 2001 Cytokine-induced inhibition of insulin release from mouse pancreatic $\beta$-cells deficient in inducible nitric oxide synthase. Biochemical and Biophysical Research Communications 281 396-403. (doi:10.1006/bbrc.2001.4361)

Bach SP, Renehan AG \& Potten CS 2000 Stem cells: the intestinal stem cell as a paradigm. Carcinogenesis 21 469-476. (doi:10.1093/carcin/21.3.469)

Baggio LL \& Drucker DJ 2007 Biology of incretins: GLP-1 and GIP. Gastroenterology 132 2131-2157. (doi:10.1053/j.gastro.2007.03.054)

Basu S, Larsson A, Vessby J, Vessby B \& Berne C 2005 Type 1 diabetes is associated with increased cyclooxygenase- and cytokine-mediated inflammation. Diabetes Care 28 1371-1375. (doi:10.2337/diacare.28. 6.1371)

Bloch K, Shichman E, Vorobeychik M, Bloch D \& Vardi P 2007 Catalase expression in pancreatic $\alpha$ cells of diabetic and non-diabetic mice. Histochemistry and Cell Biology 127 227-232. (doi:10.1007/s00418006-0248-4)

Cani PD, Hoste S, Guiot Y \& Delzenne NM 2007 Dietary non-digestible carbohydrates promote L-cell differentiation in the proximal colon of rats. British Journal of Nutrition 98 32-37. (doi:10.1017/ S0007114507691648)

Chatzigeorgiou A, Harokopos V, Mylona-Karagianni C, Tsouvalas E, Aidinis V \& Kamper EF 2010 The pattern of inflammatory/antiinflammatory cytokines and chemokines in type 1 diabetic patients over time. Annals of Medicine 42 426-438. (doi:10.3109/07853890. 2010.495951)

Cnop M, Welsh N, Jonas JC, Jorns A, Lenzen S \& Eizirik DL 2005 Mechanisms of pancreatic $\beta$-cell death in type 1 and type 2 diabetes: many differences, few similarities. Diabetes 54 S97-107. (doi:10.2337/ diabetes.54.suppl_2.S97)

Corbett JA, Sweetland MA, Wang JL, Lancaster JR Jr \& McDaniel ML 1993 Nitric oxide mediates cytokine-induced inhibition of insulin secretion by human islets of Langerhans. PNAS 90 1731-1735. (doi:10.1073/ pnas.90.5.1731)

Eizirik DL, Kutlu B, Rasschaert J, Darville M \& Cardozo AK 2003 Use of microarray analysis to unveil transcription factor and gene networks contributing to $\beta$ cell dysfunction and apoptosis. Annals of the New York Academy of Sciences 1005 55-74. (doi:10.1196/annals.1288.007) http://jme.endocrinology-journals.org DOI: 10.1530/JME-14-0214
() 2015 Society for Endocrinology Printed in Great Britain 
Elsner M, Guldbakke B, Tiedge M, Munday R \& Lenzen S 2000 Relative importance of transport and alkylation for pancreatic $\beta$-cell toxicity of streptozotocin. Diabetologia 43 1528-1533. (doi:10.1007/ s001250051564)

Elsner M, Gurgul-Convey E \& Lenzen S 2008 Relation between triketone structure, generation of reactive oxygen species, and selective toxicity of the diabetogenic agent alloxan. Antioxidants \& Redox Signaling $\mathbf{1 0}$ 691-699. (doi:10.1089/ars.2007.1816)

Espersen GT, Mathiesen O, Grunnet N, Jensen S \& Ditzel J 1993 Cytokine plasma levels and lymphocyte subsets in patients with newly diagnosed insulin-dependent (type 1) diabetes mellitus before and following initial insulin treatment. APMIS: Acta Pathologica, Microbiologica, et Immunologica Scandinavica 101 703-706. (doi:10.1111/j.1699-0463. 1993.tb00168.x)

Flatt PR \& Bailey CJ 1981 Abnormal plasma glucose and insulin responses in heterozygous lean (ob/+) mice. Diabetologia 20 573-577. (doi:10.1007/BF00252768)

Gao Y, Parker GJ \& Hart GW 2000 Streptozotocin-induced $\beta$-cell death is independent of its inhibition of $O$-GlcNAcase in pancreatic Min 6 cells. Archives of Biochemistry and Biophysics 383 296-302. (doi:10.1006/ abbi.2000.2094)

Gribble FM 2012 The gut endocrine system as a coordinator of postprandial nutrient homoeostasis. Proceedings of the Nutrition Society 71 456-462. (doi:10.1017/S0029665112000705)

Gribble FM, Williams L, Simpson AK \& Reimann F 2003 A novel glucosesensing mechanism contributing to glucagon-like peptide-1 secretion from the GLUTag cell line. Diabetes 52 1147-1154. (doi:10.2337/ diabetes.52.5.1147)

Gurzov EN, Ortis F, Bakiri L, Wagner EF \& Eizirik DL 2008 JunB inhibits ER stress and apoptosis in pancreatic $\beta$ cells. PLoS ONE $\mathbf{3}$ e3030. (doi:10.1371/journal.pone.0003030)

Hamaguchi K \& Leiter EH 1990 Comparison of cytokine effects on mouse pancreatic $\alpha$-cell and $\beta$-cell lines. Viability, secretory function, and MHC antigen expression. Diabetes 39 415-425. (doi:10.2337) diab.39.4.415)

Hammed IK, Rashid NF \& Abed BA 2012 Serum interleukin-6 level in children with type 1 diabetes mellitus. Journal of the Faculty of Medicine, Baghdad 54 228-230.

Hanifi-Moghaddam P, Schloot NC, Kappler S, Seißler J \& Kolb H 2003 An association of autoantibody status and serum cytokine levels in type 1 diabetes. Diabetes 52 1137-1142. (doi:10.2337/diabetes.52.5.1137)

Ho N, Brookshire BR, Clark JE \& Lucki I 2014 Indomethacin reverses decreased hippocampal cell proliferation in streptozotocin-induced diabetic mice. Metabolic Brain Disease [in press]. (doi:10.1007/ s11011-014-9611-7)

Holst JJ 2007 The physiology of glucagon-like peptide 1. Physiological Reviews 87 1409-1439. (doi:10.1152/physrev.00034.2006)

Huml M, Kobr J, Siala K, Varvařovská J, Pomahačová R, Karlíková M \& Sýkora J 2011 Gut peptide hormones and pediatric type 1 diabetes mellitus. Physiological Research 60 647-658.

Irwin N, Frizelle P, Montgomery IA, Moffett RC, O'Harte FP \& Flatt PR 2012 Beneficial effects of the novel cholecystokinin agonist (pGlu-Gln)-CCK8 in mouse models of obesity/diabetes. Diabetologia 55 2747-2758. (doi:10.1007/s00125-012-2654-6)

Kappe C, Zhang Q, Nyström T \& Sjöholm A 2014 Effects of high-fat diet and the anti-diabetic drug metformin on circulating GLP-1 and the relative number of intestinal L-cells. Diabetology \& Metabolic Syndrome 670. (doi:10.1186/1758-5996-6-70)

Kelly C, McClenaghan NH \& Flatt PR 2011 Role ofisletstructure and cellular interactions in the control of insulin secretion. Islets 3 41-47. (doi:10.4161/isl.3.2.14805)

Kempaiah P \& Kisiel W 2008 Human tissue factor pathway inhibitor-2 induces caspase-mediated apoptosis in a human fibrosarcoma cell line. Apoptosis 13 702-715. (doi:10.1007/s10495-008-0207-8)

Kharroubi I, Ladriere L, Cardozo AK, Dogusan Z, Cnop M \& Eizirik DL 2004 Free fatty acids and cytokines induce pancreatic $\beta$-cell apoptosis by different mechanisms: role of nuclear factor- $\mathrm{B}$ and endoplasmic reticulum stress Endocrinology 145 5087-5096. (doi:10.1210/en.2004-0478)

Kielgast U, Holst JJ \& Madsbad S 2011 Antidiabetic actions of endogenous and exogenous GLP-1 in type 1 diabetic patients with and without residual $\beta$-cell function. Diabetes 60 1599-1607. (doi:10.2337/db101790)

Kolb H 1987 Mouse models of insulin dependent diabetes: low-dose streptozocin-induced diabetes and nonobese diabetic (NOD) mice. Diabetes/Metabolism Reviews 3 751-778. (doi:10.1002/dmr.5610030308)

Kolb-Bachofen V, Epstein S, Kiesel U \& Kolb H 1988 Low-dose streptozocininduced diabetes in mice. Electron microscopy reveals single-cell insulitis before diabetes onset. Diabetes 37 21-27. (doi:10.2337/diab. 37.1.21)

Lakey JR, Suarez-Pinzon WL, Strynadka K, Korbutt GS, Rajotte RV, Mabley JG, Szabó C \& Rabinovitch A 2001 Peroxynitrite is a mediator of cytokine-induced destruction of human pancreatic islet $\beta$ cells. Laboratory Investigation 81 1683-1692. (doi:10.1038/labinvest. 3780381)

Larsen L, Tonnesen M, Ronn SG, Størling J, Jørgensen S, Mascagni P, Dinarello CA, Billestrup N \& Mandrup-Poulsen T 2007 Inhibition of histone deacetylases prevents cytokine-induced toxicity in $\beta$ cells. Diabetologia 50 779-789. (doi:10.1007/s00125-006-0562-3)

Lechleitner M, Koch T, Herold M, Dzien A \& Hoppichler F 2000 Tumour necrosis factor- $\alpha$ plasma level in patients withtype 1 diabetes mellitusand its association with glycaemic control and cardiovascular risk factors. Journal of Internal Medicine 248 67-76. (doi:10.1046/j.13652796.2000.00705.x)

Lees Murdock DJ, Barnett YA \& Barnett CR 2004 DNA damage and cytotoxicity in pancreatic $\beta$-cells expressing human CYP2E1. Biochemical Pharmacology 68 523-530. (doi:10.1016/j.bcp.2004.04.008)

Lenzen S 2008 The mechanisms of alloxan- and streptozotocin-induced diabetes. Diabetologia 51 216-226. (doi:10.1007/s00125-007-0886-7)

Li Z, Karlsson FA \& Sandler S 2000 Islet loss and $\alpha$ cell expansion in type 1 diabetes induced by multiple low-dose streptozotocin administration in mice. Journal of Endocrinology 165 93-99. (doi:10.1677/joe.0. 1650093)

Lortz S, Tiedge M, Nachtwey T, Karlsen AE, Nerup J \& Lenzen S 2000 Protection of insulin-producing RINm5F cells against cytokinemediated toxicity through overexpression of antioxidant enzymes. Diabetes 49 1123-1130. (doi:10.2337/diabetes.49.7.1123)

Lukić ML, Stosić-Grujicić S \& Shahin A 1998 Effector mechanisms in low-dose streptozotocin-induced diabetes. Developmental Immunology 6 119-128. (doi:10.1155/1998/92198)

Mechlovich D, Amit T, Mandel SA, Bar-Am O, Bloch K, Vardi P \& Youdim MB 2010 The novel multifunctional, iron-chelating drugs M30 and HLA20 protect pancreatic $\beta$-cell lines from oxidative stress damage. Journal of Pharmacology and Experimental Therapeutics 333 874-882. (doi:10.1124/ jpet.109.164269)

Meerza D, Naseem I \& Ahmed J 2012 Effect of 1, 25(OH $)_{2}$ Vitamin $\mathrm{D}_{3}$ on glucose homeostasis and DNA damage in type 2 diabetic mice. Journal of Diabetes and its Complications 26 363-368. (doi:10.1016/j. jdiacomp.2012.05.013)

Meier JJ, Ueberberg S, Korbas S \& Schneider S 2011 Diminished glucagon suppression after $\beta$-cell reduction is due to impaired $\alpha$-cell function rather than an expansion of $\alpha$-cell mass. American Journal of Physiology. Endocrinology and Metabolism 300 E717-E723. (doi:10.1152/ajpendo. 00315.2010)

Moore F, Naamane N, Colli ML, Bouckenooghe T, Ortis F, Gurzov EN, Igoillo-Esteve M, Mathieu C, Bontempi G, Thykjaer T et al. 2011 STAT1 is a master regulator of pancreatic $\beta$-cell apoptosis and islet inflammation. Journal of Biological Chemistry 286 929-941. (doi:10.1074/jbc. M110.162131)

Moore F, Santin I, Nogueira TC, Gurzov EN, Marchetti P \& Eizirik DL 2012 The transcription factor C/EBP $\delta$ has anti-apoptotic and anti-inflammatory roles in pancreatic $\beta$ cells. PLOS ONE 7 e31062. (doi:10.1371/ journal.pone.0031062) 
Mosmann T 1983 Rapid colorimetric assay for cellular growth and survival: application to proliferation and cytotoxicity assays. Journal of Immunological Methods 65 55-63. (doi:10.1016/0022-1759(83)90303-4)

Noor R, Astuti I \& Mustofa 2014 Cytotoxicity of $\alpha$-terpineol in HeLa cell line and its effects to apoptosis and cell cycle. Journal of the Medical Sciences 46 1-9.

Pacher P, Beckman JS \& Liaudet L 2007 Nitric oxide and peroxynitrite in health and disease. Physiological Reviews 87 315-424. (doi:10.1152/ physrev.00029.2006)

Peterson JD, Pike B, McDuffie M \& Haskins K 1994 Islet-specific T cell clones transfer diabetes to nonobese diabetic (NOD) F1 mice. Journal of Immunology 153 2800-2806.

Potten CS 1992 The significance of spontaneous and induced apoptosis in the gastrointestinal tract of mice. Cancer Metastasis Reviews 11 179-195. (doi:10.1007/BF00048063)

Roth KA, Hertz JM \& Gordon JI 1990 Mapping enteroendocrine cell populations in transgenic mice reveals an unexpected degree of complexity in cellular differentiation within the gastrointestinal tract. Journal of Cell Biology 110 1791-1801. (doi:10.1083/jcb.110.5. 1791)

Sarikonda G, Sachithanantham S, Pettus J, Rodriguez-Calvo T, Phatak S, Edelman S \& von Herrath M 2014 Higher proinflammatory cytokine production and spontaneous activation in some type 1 and type 2 diabetic subjects. Clinical Immunology 155 27-29. (doi:10.1016/j.clim. 2014.08.007)

Schonhoff SE, Giel-Moloney M \& Leiter AB 2004 Minireview: development and differentiation of gut endocrine cells. Endocrinology 145 2639-2644. (doi:10.1210/en.2004-0051)

Shehata AM, Quintanilla-Fend L, Bettio S, Singh CB \& Ammon HP 2011 Prevention of multiple low-dose streptozotocin (MLD-STZ) diabetes in mice by an extract from gum resin of Boswellia serrata (BE). Phytomedicine 18 1037-1044. (doi:10.1016/j.phymed.2011.06.035)

Sigfrid LA, Cunningham JM, Beeharry N, Lortz S, Tiedge M, Lenzen S, Carlsson C \& Green IC 2003 Cytokines and nitric oxide inhibit the enzyme activity of catalase but not its protein or mRNA expression in insulin-producing cells. Journal of Molecular Endocrinology 31 509-518. (doi:10.1677/jme.0.0310509)

Sirota NP, Zhanataev AK, Kuznetsova EA, Khizhnyak EP, Anisina EA \& Durnev AD 2014 Some causes of inter-laboratory variation in the results of comet assay. Mutation Research 770 16-22. (doi:10.1016/j.mrgentox. 2014.05.003)

Souza KL, Elsner M, Mathias PC, Lenzen S \& Tiedge M 2004 Cytokines activate genes of the endocytotic pathway in insulin-producing RINm5F cells. Diabetologia 47 1292-1302. (doi:10.1007/s00125004-1435-2)

Sternesjo J, Welsh N \& Sandler S 1997 S-methyl-L-thiocitrulline counteracts interleukin $1 \beta$ induced suppression of pancreatic islet function in vitro, but does not protect against multiple low-dose streptozotocin-induced diabetes in vivo. Cytokine 9 352-359. (doi:10. 1006/cyto.1996.0176)

Takeda Y, Fujita Y, Honjo J, Yanagimachi T, Sakagami H, Takiyama Y, Makino Y, Abiko A, Kieffer TJ \& Haneda M 2012 Reduction of both $\beta$ cell death and $\alpha$ cell proliferation by dipeptidyl peptidase- 4 inhibition in astreptozotocin-induced model of diabetes in mice. Diabetologia $\mathbf{5 5}$ 404-412. (doi:10.1007/s00125-011-2365-4)

Unger J 2013 Rationale use of GLP-1 receptor agonists in patients with type 1 diabetes. Current Diabetes Reports 13 663-668. (doi:10.1007/ s11892-013-0404-x)

Vasu S, Moffett RC, Thorens B \& Flatt PR 2014a Role of endogenous GLP-1 and GIP in $\beta$ cell compensatory responses to insulin resistance and cellular stress. PLOS ONE 9 e101005. (doi:10.1371/journal.pone. 0101005)

Vasu S, McClenaghan NH, McCluskey JT \& Flatt PR 2014b Mechanisms of toxicity by proinflammatory cytokines in a novel human pancreatic $\beta$ cell line, 1.1B4. Biochimica et Biophysica Acta 1840 136-145. (doi:10.1016/j.bbagen.2013.08.022)

Vilsboll T, Krarup T, Sonne J, Madsbad S, Vølund A, Juul AG \& Holst JJ 2003 Incretin secretion in relation to meal size and body weight in healthy subjects and people with type 1 and type 2 diabetes mellitus. Journal of Clinical Endocrinology and Metabolism 88 2706-2713. (doi:10.1210/jc.2002-021873)

Yoon KH, Ko SH, Cho JH, Lee JM, Ahn YB, Song KH, Yoo SJ, Kang MI, Cha BY, Lee KW et al. 2003 Selective $\beta$-cell loss and $\alpha$-cell expansion in patients with type 2 diabetes mellitus in Korea. Journal of Clinical Endocrinology and Metabolism 88 2300-2308. (doi:10.1210/ jc.2002-020735)

Zhang B, Lu Y, Campbell-Thompson M, Spencer T, Wasserfall C, Atkinson M \& Song S $2007 \alpha 1$-antitrypsin protects $\beta$-cells from apoptosis. Diabetes 56 1316-1323. (doi:10.2337/db06-1273)

Received in final form 16 December 2014

Accepted 19 December 2014

Accepted Preprint published online 19 December 2014
() 2015 Society for Endocrinology Printed in Great Britain
Published by Bioscientifica Ltd. 